\title{
Ellipsis
}

2021

\section{Tiny Masters}

Destiny Hayes

Follow this and additional works at: https://scholarworks.uno.edu/ellipsis

\section{Recommended Citation}

Hayes, Destiny (2021) "Tiny Masters," Ellipsis: Vol. 46 , Article 22.

DOI: https://doi.org/10.46428/ejail.46.22

Available at: https://scholarworks.uno.edu/ellipsis/vol46/iss1/22

This Essay is brought to you for free and open access by the Department of English and Foreign Languages at ScholarWorks@UNO. It has been accepted for inclusion in Ellipsis by an authorized editor of ScholarWorks@UNO. For more information, please contact scholarworks@uno.edu. 


\section{Tiny Masters \\ by Destiny Hayes}

One thing that I mastered is caring for and helping people that I care about no matter the wrong that they have done to me, even if I slowly lose myself. I have always been a loving and caring person, but I learned to enhance it more through family, friends, and relationships. When you want to truly master how to care for others, you have to be compassionate towards others, but never let a person mentally hurt and drain you. I made the mistake of letting my heart control my mind by letting a guy I was dating walk all over me, but I don't regret the love that I gave.

Now this is going to be a long story about how I was almost discouraged to stop loving and caring so much, but then I met someone that made me feel alive again that made me want to keep giving continuous love. There was a time that I had a boyfriend named Eric that I felt I would do any and everything for and didn't even realize the whole relationship was unhealthy for me. I would get lied to and cheated on even though I did everything I possibly could just to make him happy; he'd still treat me badly, and despite his mean actions, I'd still care for him. Eric wouldn't even let me speak about how I felt. It was as if it were a crime and the blame would always be on me. I was so used to holding everything in, it was to the point I couldn't acknowledge I was conditioned. The blame was always on me; I felt like I would take a pause in life just for me to blame myself because I was blindly "in love."

After I wasn't with him anymore, there was a point in my life where any person who tried to date me wouldn't get all of me-I would just shut them out. I didn't take people seriously. I felt as though if I did try, they would just keep picking someone else over me. I didn't want to care, and I didn't want to love. I feared it, although I would still help my family, of course. Three years passed, and I was still damaged. I did not pursue any relationships. I would date people, but it would never actually be a serious relationship where I felt that I could open up to them. When it came to my love life, I felt there was no chance for me. I just did not want love, or so I thought.

Once I met my girlfriend in basic training, we had nothing but time to get to know each other, and I found myself falling in love with her. When something would upset me, she would be patient with me and ask me, "What's wrong?" I wanted to tell her, but I just couldn't. I was conditioned not to speak my mind without even realizing it. Although we had time to sit around and learn a lot of stories about each other, I was so worried that I would say something that would upset her. She felt as though I didn't trust her enough to tell her what was wrong with me. When I realized I was shutting her out, I contemplated in my head, "What should I say to her?" I didn't want to say the wrong things to her that I felt would probably ruin our relationship because that's what I was used to before with Eric.

I was stuck in my own mind, even though I was screaming from the inside to open up to her. I couldn't even make eye contact when I would have conversations with her about what 
bothered me because I already slowly broke my heart by preparing for the worst before it happened. There was never a "worst" when it came to her; she actually listened. I realized it was

a problem for me to open up when it almost drove me insane to even speak about my own feelings. I cared so much for her at that time that I forced myself to open up, and I effortlessly took care of her. It took someone so genuine for me to realize there was something wrong enough for me to change because she didn't deserve to be shut out, even though it wasn't intentional. Even to this day, we look back and see how much we grew and how much we changed. We both became more caring for others and always made sure that we were both good.

My girlfriend helped me open back up and become more caring, but it has always been a natural thing because of my mom and brother with special needs. She just enhanced it. I helped my mom take care of my grandma, who was sick and dying from cancer, when I was only ten years old. I helped her care for my brother who has autism, suffers from seizures, and is nonverbal. I am the only one that my mom trusts with my brother because we both handled him for fourteen years. Since I was little, I took on my mom's responsibility of being a natural caregiver. Although it hurts me to watch the people that I love suffer, it helped me provide care and become experienced young.

I love caring for people because it makes me feel whole, it fills not only my heart up but my whole body. Everything within me says this trait about me is pure and is meant to be exercised. I'm not sure what the true meaning behind my whole experience is, but I do know that it wasn't by accident that I experienced these things. Just from brainstorming this essay, it helped me remember memories that I thought have long been buried, but I am grateful to face all of my emotions and thoughts. These experiences have helped me become a tiny master with expanding my love and being a caregiver. 